\title{
EFFECT OF COMPOST AND SOME NATURAL STIMULANT TREATMENTS ON: I. VEGETATIVE GROWTH AND FLOWERING ASPECTS OF (GLADIOLUS GRANDIFLORUS CV. PETER PEARS) PLANTS
}

\author{
M.A.H. Abdou , F.S. Badran ${ }^{*}$, E.T. Ahmed ${ }^{*}$ R.A. Taha ${ }^{*}$ and M.A.M. Abdel-Mola ${ }^{* *}$ \\ * Hort. Dept., Fac. Agric., Minia Univ., Egypt. \\ ** Hort. Dept., Fac. Agric., Beni-Seuf Univ., Egypt.
}

\begin{abstract}
Two field experiments were carried out during the two successive seasons of 2014/2015 and 2015/2016 at the Nursery and the Laboratory of Ornamental plants, Faculty of Agriculture, Minia University. The aim of this study was to figure out the effect of organic fertilization and natural stimulants, as well as, their interaction on vegetative growth, flowering aspects of Gladiolus grandiflorus cv. Peter Pears plants.

Results showed that vegetative growth (leaf length, number of leaves/plant and dry weight of leaves/plant) and flowering aspects (length of spike, number of florets/spike and lower floret diameter) were gradually increased by increasing the level of compost fertilizer.
\end{abstract}

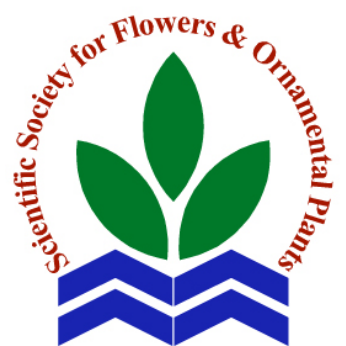

Scientific J. Flowers \& Ornamental Plants, 5(2):105-114 (2018).

Received: $17 / 2 / 2018$ Accepted: $26 / 2 / 2018$

All natural stimulant treatments significantly increased all vegetative growth characters and flowering parameters in comparison with the control. Seaweeds extract at $3 \mathrm{~cm}^{3} / 1$ or active dry yeast at $5 \mathrm{~g} / \mathrm{l}$ seemed to be more effective than other treatments in this concern.

The use of high level of compost (7.5 ton/fed) in combination with seaweeds extract at $3 \mathrm{~cm}^{3} / 1$ or active dry yeast at $5 \mathrm{~g} / \mathrm{l}$ noticeably improved the different vegetative growth characters and flowering parameters of gladiolus.

Key words: Gladiolus grandiflorus, compost, seaweeds extract, active dry yeast, moringa leaves extract, green tea extract, vegetative growth, flowering parameters.

\section{INTRODUCTION}

Gladiolus grandiflorus, L. plants are considered one of the most important flowering bulbs grown in Egypt. Gladiolus belongs to Family Iridaceae and is propagated by corms. It has a decorative spike which carries numerous florets. There are fast expands in areas planted with gladiolus in Egypt in order to meet the increase demand for gladiolus flowers for local market and export.

All natural stimulants are among the important agricultural treatments which have been proved to improve the vegetative growth and flowering aspects of gladiolus plants.

Many investigators revealed the importance of organic fertilization on the growth and flowering quality of gladiolus. Gangadharan and Gopinath (2000), Conte et al. (2001), Khan et al. (2002), Atta-Alla et al. (2003), Dongardive et al. (2007), Leonardo and Barbara (2011), Chandar et al. (2012), Hassan (2016), Khanam et al. (2017) and Abdel-Mola (2017) reported that treated gladiolus plants with organic fertilization resulted in significant increase in leaf length, number of leaves and dry weight of leaves, as well as, spike length, number of 
florets/spike and lower floret diameter in comparison with untreated plants.

Concerning the effect of natural stimulants, Al-Rashedy (2010), Ahmed (2013), Abdou et al. (2013), Abdou and Ibrahim (2015), Almathedee and Bairam (2014), Hassan (2016), Khattab et al. (2016) and Abdel-Mola (2017) found that natural stimulant treatments improved vegetative growth and flowering characters of gladiolus.

The aim of the present study was to investigate the effect of compost as organic fertilizer and natural stimulant treatments on the vegetative growth and flowering productivity of gladiolus cv. Peter Pears.

\section{MATERIALS AND METHODS}

The corms of gladiolus were obtained from Holland by Basiouny Nurseries, Cairo, Egypt. Average corm diameter was 2.7 and $3.0 \mathrm{~cm}$ and average corm weight was 9.7 and $10.2 \mathrm{~g}$ for the two seasons, respectively, all corms were soaked in Pinlate at the concentration of $1 \mathrm{~g} / \mathrm{l}$ for one minute before planting in the two experimental seasons. Corms were planted on October $1^{\text {st }}$ for both seasons in hills, $20 \mathrm{~cm}$ apart, on the lower third of one side of each ridge (10 corms/ridge). Physical and chemical properties of the soil used are listed in Table (1). The split plot design with three replicates was followed in this experiment.

The four levels of compost fertilization treatments were considered as main plots and the seven natural stimulant treatments (control, green tea extract at $5 \mathrm{~g} / \mathrm{l}$, moringa leaves extract at $300 \mathrm{mg} / \mathrm{l}$, garlic extract at $300 \mathrm{mg} / \mathrm{l}$, licorice roots extract at $5 \mathrm{~g} / \mathrm{l}$, active dry yeast at $5 \mathrm{~g} / \mathrm{l}$ and seaweeds extract at $3 \mathrm{~cm}^{3} / \mathrm{l}$ ) were set in the sub-plots. The four levels of compost treatments were 0.0, 2.5, 5.0 and 7.5 ton/fed. The compost was added before planting during the soil preparation. Compost analysis is shown in Table (2).

The plants were foliar sprayed three times, one month and two months after planting and after flower cut. All agricultural practices were performed as usual in the region.

\section{Preparation of the natural stimulants:}

\section{Garlic plant extract:}

One kilogram fresh mature cloves were blended in the presence of distilled water (1 $\mathrm{kg} / \mathrm{l}$ ), then frozen (24 hours) and thawed two times then filtered. The filter extract (100\%) was used for preparation $(300 \mathrm{ml} / \mathrm{l}=30 \%)$ according to El-Desouky et al. (1998).

Some chemical constituents of garlic according cloves to Arid Land Agricultural Research Unit are listed in Table (3).

\section{Moringa leaves extract:}

Aqueous extract of moringa at $(300 \mathrm{ml} / \mathrm{l})$ was prepared by mixing $30 \mathrm{~g}$ of plant leaf material with one liter of distilled water in a household blender for $15 \mathrm{~min}$ at $50{ }^{\circ} \mathrm{C}$. The solution was filtered through filtered paper (Phiri and Mbewe, 2010). Nutrient information and amino acids of moringa leaves were shown in Table (4).

Table 1. Physical and chemical properties of the experimental soil.

\begin{tabular}{|c|c|c|c|c|c|}
\hline \multirow{2}{*}{ Character } & \multicolumn{2}{|c|}{ Value } & \multirow{2}{*}{ Character } & \multicolumn{2}{|c|}{ Value } \\
\hline & $2014 / 2015$ & $2015 / 2016$ & & 2014/2015 & $2015 / 2016$ \\
\hline Sand (\%) & 28.98 & 28.90 & Total N (\%) & 0.08 & 0.06 \\
\hline Silt (\%) & 29.87 & 30.64 & Available P (\%) & 15.67 & 15.58 \\
\hline Clay (\%) & 41.15 & 40.46 & Exch. $K^{+}(\mathrm{mg} / 100 \mathrm{~g})$ & 2.85 & 2.64 \\
\hline Soil type & Clay loam & Clay loam & Exch. $\mathrm{Ca}^{++}(\mathrm{mg} / 100 \mathrm{~g})$ & 31.12 & 31.43 \\
\hline Organic matter (\%) & 1.54 & 1.59 & Exch. $\mathrm{Na}^{+}$(mg/100 g) & 2.51 & 2.50 \\
\hline $\mathrm{CaCO}_{3}(\%)$ & 2.11 & 2.10 & $\mathbf{F e}$ & 8.23 & 8.11 \\
\hline pH & 7.75 & 7.71 & DPTA & 2.01 & 2.00 \\
\hline E.C. $(\mathrm{mmhos} / \mathrm{cm})$ & 1.08 & 1.06 & Ext. (ppm) Zn & 2.87 & 2.89 \\
\hline & & & Mn & 8.11 & 8.15 \\
\hline
\end{tabular}


Table 2. The chemical analysis of compost.

\begin{tabular}{lclc}
\hline \multicolumn{1}{c}{ Content } & Value & \multicolumn{1}{c}{ Content } & Value \\
Organic carbon (\%) & 25.1 & Total P (\%) & 0.5 \\
Humidity (\%) & 25 & Total K (\%) & 1.0 \\
Organic matter & 44 & Fe (ppm) & 1750 \\
C/N ratio & 16.7 & Zn (ppm) & 60 \\
pH (1:2.5) & 8.0 & Mn (ppm) & 125 \\
E.C. (mmhos/cm) & 5 & Cu (ppm) & 200 \\
Total N (\%) & 2.2 & & \\
\hline
\end{tabular}

Table 3. Some chemical constituents of garlic according cloves to Arid Land Agricultural Research Unit:

\begin{tabular}{|c|c|c|c|c|c|c|c|c|}
\hline Components & $\mathbf{G A}_{3}$ & IAA & ABA & $\mathrm{Ca}^{+2}$ & $\mathrm{Mg}^{+2}$ & $\mathrm{SO}_{4}^{-2}$ & $\mathrm{Zn}^{+2}$ & $\mathrm{Mn}^{+2}$ \\
\hline Concentration & $\begin{array}{c}16.33 \\
\text { (mg/100 g } \\
\text { f.w.) }\end{array}$ & Trace & Trace & $\begin{array}{c}1.363 \\
\%\end{array}$ & $\begin{array}{c}1.230 \\
\%\end{array}$ & $\begin{array}{c}0.181 \\
\%\end{array}$ & $\begin{array}{l}66.5 \\
\text { ppm }\end{array}$ & $\begin{array}{l}94.4 \\
\text { ppm }\end{array}$ \\
\hline
\end{tabular}

Table 4. Nutrients information and amino acids of moringa leaves.

\begin{tabular}{lclclc}
\hline Nutrient information & Leaves & Nutrient information & Leaves & Amino acids & Leaves \\
\hline Calories & 92 & Sulfur (mg) & 137 & Arginine & 402 \\
Protein (g) & 6.7 & Selenium (mg) & 0 & Histidine & 141 \\
Fat (g) & 1.7 & Zinc (mg) & 0 & Isoleucine & 422 \\
Carbohydrate (g) & 13.4 & Oxalic Acid (mg) & 101 & Leucine & 623 \\
Fiber (g) & 0.9 & Vitamin A (mg) & 6.8 & Lysine & 288 \\
Calcium (mg) & 440 & Vitamin B (mg) & 423 & Methionine & 134 \\
Copper (mg) & 1.1 & Vitamin B $\mathbf{( m g )}$ & 0.21 & Phenylalanine & 429 \\
Iron (mg) & 7 & Vitamin B $\mathbf{( m g )}$ & 0.05 & Threonine & 328 \\
Potassium (mg) & 259 & Vitamin B $\mathbf{~ ( m g ) ~}$ & 0.8 & Tryptophan & 127 \\
Magnesium (mg) & 24 & Vitamin C (mg) & 220 & & \\
Phosphorus (mg) & 70 & Vitamin E (mg) & 0 & & \\
\hline
\end{tabular}

\section{Green tea extract:}

The aqueous extract is prepared in ratio 1:10 with the consideration of the absorption coefficient of green tea leaves. Technology of preparation $-5 \mathrm{~g}$ of tea leaves of diameter lower than $5 \mathrm{~mm}$ are poured with $60 \mathrm{ml}$ of boiling water. Time is given for the extraction to cool down and the quality of these extracts has been evaluated after 10, 20 and $30 \mathrm{~min}$ according to Armoskaite et al. (2011).

\section{Active dry yeast:}

The dry matter of active dry yeast (Saccharomyces cerevisiae), was $95 \%$ and live cells were $11.6 \times 10^{9} / \mathrm{g}$. The yeast suspension was prepared by dissolving dry yeast and sugar together $(1: 1) \mathrm{w} / \mathrm{w}$ in warm water $\left(38{ }^{\circ} \mathrm{C}\right)$ and let it stand for two hours before spraying to enhance yeast activity (Skoog and Miller, 1957). Chemical analysis of the dry yeast is presented in Table (5).

\section{Licorice roots extract:}

Preparation of licorice extract soaked grinded dry licorice roots (5 g) in distilled water (1 liter) for 24 hours and then filtered using filter paper. The active components in licorice roots extract contains of volatile oils, tannins, carbohydrates, saponins, phenols, glycosides, flavonoids and fixed oils. The elements analysis in licorice roots extract contains of $\mathrm{K}, \mathrm{Ca}, \mathrm{Fe}, \mathrm{P}, \mathrm{Mg}, \mathrm{SO}_{4}, \mathrm{~N}, \mathrm{Na}$, Mn, Zn and Co. Abd El-Azim et al. (2016). 
Table 5. Chemical composition of the used active dry yeast.

\begin{tabular}{lclclc}
\hline Component & Value & Component & Value & Component & Value \\
\hline Cu (mg/g) & 8.0 & Fe (mg/g) & 0.02 & Niacin & $300-500 \mathrm{mg} / \mathrm{g}$ \\
Se (mg/g) & 0.1 & $\mathbf{M g}(\mathbf{m g} / \mathbf{g})$ & 1.65 & Pyrodoxin & $28.0 \mathrm{mg} / \mathrm{g}$ \\
$\mathbf{M n}(\mathbf{m g} / \mathbf{g})$ & 0.02 & $\mathbf{K}(\mathbf{m g} / \mathbf{g})$ & 21.0 & Pantathenate & $70.0 \mathrm{mg} / \mathrm{g}$ \\
$\mathbf{C r}(\mathbf{m g} / \mathbf{g})$ & 2.2 & $\mathbf{P}(\mathbf{m g} / \mathbf{g})$ & 13.50 & Bioton & $1.3 \mathrm{mg} / \mathrm{g}$ \\
$\mathbf{N i}(\mathbf{m g} / \mathbf{g})$ & 3.0 & $\mathbf{S}(\mathbf{m g} / \mathbf{g})$ & 3.90 & Cholin & $40.0 \mathrm{mg} / \mathrm{g}$ \\
$\mathbf{V a}(\mathbf{m g} / \mathbf{g})$ & 0.04 & $\mathbf{Z n ~ ( m g / g )}$ & 0.17 & Folic acid & $5.13 \mathrm{mg} / \mathrm{g}$ \\
$\mathbf{M o}(\mathbf{m g} / \mathbf{g})$ & 0.4 & Si (mg/g) & 0.03 & Vit B12 & $0.001 \mathrm{mg} / \mathrm{g}$ \\
$\mathbf{S n}(\mathbf{m g} / \mathbf{g})$ & 3.0 & Proteins & $47 \%$ & Thiamine & $60-100 \mathrm{ml} / \mathrm{g}$ \\
$\mathbf{L i}(\mathbf{m g} / \mathbf{g})$ & 0.17 & Carbohydrates & $33.0 \%$ & Riboflavin & $35-50 \mathrm{ml} / \mathrm{g}$ \\
$\mathbf{N a ~ ( m g / g ) ~}$ & 0.12 & Minerals & $8.0 \%$ & Lipids & $4.0 \%$ \\
$\mathbf{C a}(\mathbf{m g} / \mathbf{g})$ & 0.75 & Nucleic acids & $8.0 \%$ & & \\
\hline
\end{tabular}

The elements of licorice analysis roots extract listed in Table (6).

\section{Seaweeds extract:}

Algeser product contains seaweed extract from (Shoura Chemicals Company, Cairo Alex Desert RD., Giza Governorate). The chemical properties of the seaweeds extract shown in Table (7).

Agricultural practices were performed as usual, in the region. The following data were recorded:
1. Vegetative growth characters just before flowering: leaf length $(\mathrm{cm})$, number of leaves/plant and dry weight of leaves (g/plant).

2. Flowering characters: spike length $(\mathrm{cm})$, number of florets/spike and lower floret diameter $(\mathrm{cm})$.

All of the obtained data were subjected to the statistical analysis of variance using MSTAT-C (1986). L.S.D. test at 0.05 was used to compare the average means of treatments.

Table 6. The elements of licorice analysis roots extract.

\begin{tabular}{cccccccccccc}
\hline Elements & $\mathbf{K}^{+\mathbf{1}}$ & $\mathbf{C a}^{+2}$ & $\mathbf{F e}^{+3}$ & $\mathbf{P}^{-3}$ & $\mathbf{M g}^{+2}$ & $\mathbf{S O}^{-2}$ & $\mathbf{N}^{-3}$ & $\mathbf{N a}^{+\mathbf{1}}$ & $\mathbf{M n}^{+2}$ & $\mathbf{Z n}^{+2}$ & $\mathbf{C o}^{+2}$ \\
\hline $\mathbf{p p m}$ & 1230 & 500 & 1400 & 520 & 5 & 900 & 16500 & 700 & 1700 & 35000 & 0.07 \\
\hline
\end{tabular}

Table 7. The chemical properties of the seaweeds extract.

\begin{tabular}{lclclc}
\multicolumn{1}{c}{ Character } & Values & \multicolumn{1}{c}{ Character } & Values & \multicolumn{1}{c}{ Character } & Values \\
\hline Moisture \% & 6.0 & K \% & $1.0-1.2$ & Cu ppm & $1.0-6.0$ \\
Organic matter \% & $45-60$ & Mg \% & $0.5-0.9$ & Mn ppm & $5-12$ \\
Inorganic matter \% & $45-60$ & $\mathbf{P}$ \% & $0.02-0.09$ & Zn ppm & $10-100$ \\
Protein \% & $6-8$ & $\mathbf{S} \%$ & $3-9$ & Cytokinins \% & 0.02 \\
Carbohydrate \% & $35-50$ & Ca \% & $0.2-1.5$ & IAA \% & 0.03 \\
Aliginic acid \% & $10-20$ & B ppm & $20-100$ & ABA \% & 0.01 \\
Mannitol \% & $4-7$ & Mo ppm & $1-5$ & & \\
Total N \% & $1.0-1.5$ & Fe ppm & $50-200$ & & \\
\hline
\end{tabular}

\section{RESULTS AND DISCUSSION}

\section{Vegetative growth characters:}

Data presented in Table (8) showed that leaf length, number of leaves/plant and leaves dry weight/plant of gladiolus were significantly increased in both seasons due to the use of compost at 2.5, 5.0 and 7.5 ton/fed in comparison with control. The highest values were obtained from compost at high 
Table 8. Effect of compost and natural stimulants, as well as, their combination treatments on vegetative growth [leaf length $(\mathrm{cm})$, number of leaves/plant \& leaves dry weight/plant (g)] of Gladiolus grandiflorus cv. Peter Pears plants during 2014/2015 and 2015/2016 seasons.

\begin{tabular}{|c|c|c|c|c|c|c|c|c|c|c|}
\hline \multirow{3}{*}{$\begin{array}{l}\text { Natural stimulants } \\
\text { treatments (B) }\end{array}$} & \multicolumn{10}{|c|}{ Compost levels (ton/fed) (A) } \\
\hline & \multicolumn{5}{|c|}{$1^{\text {st }} \operatorname{season}(2014 / 2015)$} & \multicolumn{5}{|c|}{$2^{\text {nd }}$ season $(2015 / 2016)$} \\
\hline & 0.0 & 2.5 & 5.0 & 7.5 & $\begin{array}{c}\text { Mean } \\
\text { (B) }\end{array}$ & 0.0 & 2.5 & 5.0 & 7.5 & $\begin{array}{c}\text { Mean } \\
(B)\end{array}$ \\
\hline \multicolumn{11}{|c|}{ Leaf length (cm) } \\
\hline Control & 37.25 & 42.05 & 49.10 & 51.24 & 44.91 & 38.35 & 43.16 & 50.21 & 52.35 & 46.02 \\
\hline Green tea extr. 5 g/l & 46.40 & 50.03 & 54.03 & 56.41 & 51.72 & 47.04 & 51.24 & 55.24 & 57.61 & 52.78 \\
\hline Moringa extr. 300 mg/l & 48.30 & 50.13 & 54.18 & 56.32 & 52.23 & 49.50 & 51.43 & 55.49 & 57.61 & 53.51 \\
\hline Garlic extr. 300 mg/l & 48.36 & 52.24 & 56.22 & 59.11 & 53.98 & 49.57 & 53.52 & 57.51 & 60.20 & 55.20 \\
\hline Licorice extr. 5 g/l & 50.10 & 55.11 & 57.14 & 63.44 & 56.45 & 51.40 & 56.32 & 58.43 & 64.74 & 57.72 \\
\hline Active yeast $5 \mathrm{~g} / \mathrm{l}$ & 51.20 & 55.52 & 59.08 & 64.30 & 57.53 & 52.49 & 56.81 & 60.37 & 65.59 & 58.82 \\
\hline Seaweeds extr. $3 \mathrm{~cm}^{3} / \mathbf{l}$ & 51.82 & 55.03 & 59.11 & 64.88 & 57.71 & 53.13 & 56.34 & 60.42 & 66.19 & 59.02 \\
\hline Mean (A) & 47.63 & 51.44 & 55.55 & 59.39 & & 48.78 & 52.69 & 56.81 & 60.61 & \\
\hline L.S.D. at $5 \%$ & \multicolumn{2}{|c|}{ A: 3.43} & B: 6.12 & \multicolumn{2}{|c|}{ AB: 12.24} & \multicolumn{2}{|c|}{ A: 3.30} & B: 6.04 & \multicolumn{2}{|c|}{ AB: 12.08} \\
\hline \multicolumn{11}{|c|}{ Number of leaves/plant } \\
\hline Control & 6.75 & 7.33 & 8.60 & 9.24 & 7.98 & 7.65 & 8.24 & 9.62 & 10.18 & 8.92 \\
\hline Green tea extr. 5 g/l & 8.41 & 8.49 & 9.01 & 9.47 & 8.85 & 9.37 & 9.45 & 10.10 & 10.46 & 9.85 \\
\hline Moringa extr. 300 mg/l & 8.44 & 8.94 & 8.97 & 9.95 & 9.08 & 9.52 & 9.90 & 10.06 & 10.95 & 10.11 \\
\hline Garlic extr. 300 mg/l & 8.72 & 9.05 & 9.63 & 9.99 & 9.35 & 9.69 & 10.02 & 10.14 & 11.00 & 10.21 \\
\hline Licorice extr. 5 g/l & 9.00 & 9.81 & 9.54 & 10.11 & 9.62 & 9.98 & 10.79 & 10.65 & 11.03 & 10.61 \\
\hline Active yeast $5 \mathrm{~g} / \mathrm{l}$ & 10.24 & 10.54 & 10.86 & 11.71 & 10.84 & 11.22 & 11.52 & 11.99 & 12.73 & 11.87 \\
\hline Seaweeds extr. $3 \mathrm{~cm}^{3} / \mathbf{l}$ & 10.66 & 10.92 & 10.96 & 11.87 & 11.10 & 11.65 & 11.93 & 12.10 & 12.91 & 12.15 \\
\hline Mean (A) & 8.89 & 9.30 & 9.65 & 10.33 & & 9.87 & 10.26 & 10.67 & 11.32 & \\
\hline L.S.D. at $5 \%$ & \multicolumn{2}{|c|}{ A: 0.38} & B: 0.80 & \multicolumn{2}{|c|}{$\mathrm{AB}: 1.60$} & \multicolumn{2}{|c|}{ A: 0.35} & B: 0.86 & \multicolumn{2}{|c|}{$\mathrm{AB}: 1.72$} \\
\hline \multicolumn{11}{|c|}{ Leaves dry weight/plant (g) } \\
\hline Control & 3.00 & 3.66 & 4.63 & 5.01 & 4.08 & 3.22 & 4.16 & 5.15 & 5.50 & 4.51 \\
\hline Green tea extr. 5 g/l & 3.44 & 3.99 & 4.62 & 4.96 & 4.25 & 3.94 & 4.50 & 5.19 & 5.57 & 4.80 \\
\hline Moringa extr. 300 mg/l & 3.42 & 4.07 & 4.70 & 5.10 & 4.32 & 3.92 & 4.60 & 5.28 & 5.64 & 4.86 \\
\hline Garlic extr. 300 mg/l & 3.57 & 4.40 & 4.98 & 5.38 & 4.58 & 4.07 & 4.93 & 5.54 & 5.97 & 5.13 \\
\hline Licorice extr. 5 g/l & 3.76 & 4.43 & 4.94 & 5.45 & 4.65 & 4.26 & 4.96 & 5.53 & 5.95 & 5.18 \\
\hline Active yeast $5 \mathrm{~g} / \mathrm{l}$ & 3.78 & 4.81 & 5.06 & 5.64 & 4.82 & 4.21 & 5.25 & 5.56 & 6.05 & 5.27 \\
\hline Seaweeds extr. $3 \mathrm{~cm}^{3} / 1$ & 3.82 & 4.91 & 5.10 & 5.81 & 4.91 & 4.23 & 5.35 & 5.57 & 6.24 & 5.35 \\
\hline Mean (A) & 3.54 & 4.32 & 4.86 & 5.34 & & 3.98 & 4.82 & 5.40 & 5.85 & \\
\hline L.S.D. at $5 \%$ & A: 0.4 & & B: 0.15 & $\mathrm{AB}$ & $: 0.30$ & A: 0. & & B: 0.25 & $\mathrm{AB}$ & 0.50 \\
\hline
\end{tabular}


level (7.5 ton/fed). The increase of vegetative growth resulting from using compost as organic fertilization treatments might be due to the fact that organic matter is considered as an important factor for improving physical, chemical and biological properties of the soil and consequently, increased plant growth (Maynard, 1991). Similar results were obtained by Ahmed (2013), Pandey et al. (2013), Khalil (2015), Sankari et al. (2015), Hassan (2016) and Khanam et al. (2017) on gladiolus.

Data presented in Table (8) indicated that, leaf length, number of leaves/plant and leaves dry weight were significantly increased, in both seasons, due to the use of the six treatments of natural stimulants (green tea extract at $5 \mathrm{~g} / \mathrm{l}$, moringa leaves extract at $300 \mathrm{mg} / \mathrm{l}$, garlic extract at 300 $\mathrm{mg} / \mathrm{l}$, licorice roots extract at $5 \mathrm{~g} / \mathrm{l}$, active dry yeast at $5 \mathrm{~g} / \mathrm{l}$ and seaweeds extract at $3 \mathrm{~cm}^{3} / \mathrm{l}$ ) in comparison with untreated control. Seaweeds extract at $3 \mathrm{~cm}^{3} / 1$ or active dry yeast at $5 \mathrm{~g} / \mathrm{l}$ seemed to be more effective than either natural stimulants.

The role of seaweeds extracts in promoting vegetative growth might be attributed to the presence of phyto-hormones such as auxins and cytokinns. Seaweed extracts also stimulated mineral nutrient uptake in plants with increased accumulation of both macro and micro-nutrients (Crouch and Van Staden, 1992). In regard to the active dry yeast, its positive effects could be attributed to its active role in the hydrolysis of pectic substances. It is known that vitamins, enzymes and coenzymes are important components of the yeast. Also, yeast increases the release of carbon dioxide through fermentation process which effectively activates photosynthesis and accelerates biosynthesis of carbohydrates and proteins. Moreover, it increases the synthesis of plant growth promoters especially $\mathrm{GA}_{3}$, IAA and cytokinins which led to improve in cell division and cell enlargement (Moore, 1979). In addition, yeast contains different nutrients, amino acids and vitamins which promote the uptake of different nutrient elements through the modification of the $\mathrm{pH}$ value of soil solution towards acidity medium (Subba Rao, 1984).

The interaction between the two factors was significant in the two seasons for leaf length, leaf number and leaves dry weight. The maximum leaf length, number of leaves/plant and leaves dry weight/plant, were obtained due to supplying the soil with 7.5 ton/fed compost in combination with seaweeds extract at $3 \mathrm{~cm}^{3} / 1$ followed by active dry yeast at $5 \mathrm{~g} / \mathrm{l}$.

\section{Flowering parameters:}

Data presented in Table (9) show that all compost level treatments caused significant increase in length of spike, number of florets/spike and lower floret diameter, in the two seasons, in comparison with that of untreated plants. The flowering parameters were gradually increased due to the increase in the levels of compost fertilizer.

These results are in close agreement with those obtained by Khan et al. (2002); Dongardive et al. (2007); Ahmed et al. (2013), Pandey et al. (2013), Pradeep et al. (2014), Pereira et al. (2016) and Abdel-Mola (2017) on gladiolus.

A possible explanation to the positive effect of compost fertilizer treatments might be attributed to its simulative effect on the different vegetative growth traits (Table, 8). Better vegetative growth is directly reflected on various flowering aspects.

Regarding natural stimulants (green tea extract at $5 \mathrm{~g} / \mathrm{l}$, moringa leaves extract at 300 $\mathrm{mg} / \mathrm{l}$, garlic extract at $300 \mathrm{mg} / \mathrm{l}$, licorice roots extract at $5 \mathrm{~g} / \mathrm{l}$, active dry yeast at $5 \mathrm{~g} / \mathrm{l}$ and seaweeds extract at $3 \mathrm{~cm}^{3} / \mathrm{l}$ ) data presented in Table (9) revealed that all six used treatments significantly increased length of spike, number of florets/spike and lower florets diameter compared with untreated plants. The highest values were obtained due to the treatments of active dry yeast at $5 \mathrm{~g} / \mathrm{l}$ followed by seaweeds extract at $3 \mathrm{~cm}^{3} / 1$ without significant differences except in case of lower florets diameter.

These findings were similar to those obtained by Ahmed (2013), Alma'thedee and Bairam (2014), Hassan (2016) and Abdou 
Table 9. Effect of compost and natural stimulants, as well as, their combination treatments on flowering aspects [spike length $(\mathrm{cm})$, number of florets/spike \& lower floret diameter (cm)] of Gladiolus grandiflorus cv. Peter Pears plants during 2014/2015 and 2015/2016 seasons.

\begin{tabular}{|c|c|c|c|c|c|c|c|c|c|c|}
\hline \multirow{3}{*}{$\begin{array}{l}\text { Natural stimulants } \\
\text { treatments (B) }\end{array}$} & \multicolumn{10}{|c|}{ Compost levels (ton/fed) (A) } \\
\hline & \multicolumn{5}{|c|}{$1^{\text {st }}$ season $(2014 / 2015)$} & \multicolumn{5}{|c|}{$2^{\text {nd }}$ season $(2015 / 2016)$} \\
\hline & 0.0 & 2.5 & 5.0 & 7.5 & $\begin{array}{c}\text { Mean } \\
\text { (B) }\end{array}$ & 0.0 & 2.5 & 5.0 & 7.5 & $\begin{array}{l}\text { Mean } \\
\text { (B) }\end{array}$ \\
\hline \multicolumn{11}{|c|}{ Spike length (cm) } \\
\hline Control & 51.08 & 53.34 & 55.21 & 60.03 & 54.92 & 52.100 & 54.54 & 56.51 & 61.33 & 56.12 \\
\hline Green tea extr. 5 g/l & 53.09 & 61.31 & 61.88 & 66.34 & 60.66 & 54.69 & 63.01 & 63.88 & 68.44 & 62.51 \\
\hline Moringa extr. 300 mg/l & 55.23 & 60.44 & 63.61 & 67.22 & 61.63 & 56.73 & 62.64 & 66.01 & 69.52 & 63.73 \\
\hline Garlic extr. 300 mg/l & 61.81 & 64.25 & 66.14 & 69.50 & 65.43 & 63.51 & 66.55 & 68.94 & 72.30 & 67.83 \\
\hline Licorice extr. 5 g/l & 66.15 & 68.04 & 68.15 & 72.31 & 68.66 & 68.55 & 71.94 & 72.75 & 80.01 & 73.31 \\
\hline Active yeast $5 \mathrm{~g} / \mathrm{l}$ & 69.03 & 70.36 & 71.13 & 73.66 & 71.05 & 72.53 & 75.36 & 78.03 & 81.04 & 76.74 \\
\hline Seaweeds extr. $3 \mathrm{~cm}^{3} / \mathrm{l}$ & 68.24 & 69.13 & 70.00 & 73.52 & 70.22 & 71.54 & 74.03 & 76.80 & 80.71 & 75.77 \\
\hline Mean (A) & 60.66 & 63.84 & 65.16 & 68.94 & & 62.81 & 66.87 & 68.99 & 73.34 & \\
\hline L.S.D. at $5 \%$ & \multicolumn{2}{|c|}{ A: 1.24} & B: 5.08 & \multicolumn{2}{|c|}{ AB: 10.16} & \multicolumn{2}{|c|}{ A: 2.08} & B: 5.94 & \multicolumn{2}{|c|}{ AB: 11.88} \\
\hline \multicolumn{11}{|c|}{ Number of florets/spike } \\
\hline Control & 7.00 & 8.33 & 9.00 & 9.67 & 8.50 & 8.00 & 9.33 & 10.00 & 10.67 & 9.50 \\
\hline Green tea extr. 5 g/l & 7.67 & 8.67 & 10.00 & 10.00 & 9.09 & 8.67 & 9.67 & 11.00 & 11.00 & 10.09 \\
\hline Moringa extr. 300 mg/l & 8.00 & 9.00 & 10.00 & 10.67 & 9.42 & 9.00 & 10.00 & 11.00 & 11.67 & 10.42 \\
\hline Garlic extr. 300 mg/l & 8.33 & 9.00 & 10.33 & 10.67 & 9.58 & 9.33 & 10.00 & 11.33 & 11.67 & 10.58 \\
\hline Licorice extr. $5 \mathrm{~g} / \mathrm{l}$ & 8.67 & 9.33 & 10.67 & 11.00 & 9.92 & 9.67 & 10.33 & 11.67 & 12.00 & 10.92 \\
\hline Active yeast $5 \mathrm{~g} / \mathrm{l}$ & 9.67 & 10.33 & 11.00 & 12.33 & 10.83 & 10.67 & 11.33 & 12.00 & 13.00 & 11.75 \\
\hline Seaweeds extr. $3 \mathrm{~cm}^{3} / \mathrm{l}$ & 9.00 & 10.00 & 10.67 & 11.67 & 10.34 & 10.00 & 10.67 & 11.67 & 12.67 & 11.25 \\
\hline Mean (A) & 8.33 & 9.24 & 10.24 & 10.86 & & 9.33 & 10.19 & 11.24 & 11.81 & \\
\hline L.S.D. at $5 \%$ & \multicolumn{2}{|c|}{ A: 0.61} & B: 0.51 & \multicolumn{2}{|c|}{ AB: 1.02} & \multicolumn{2}{|c|}{ A: 0.56} & B: 0.52 & \multicolumn{2}{|c|}{$\mathrm{AB}: 1.04$} \\
\hline \multicolumn{11}{|c|}{ Lower floret diameter $(\mathrm{cm})$} \\
\hline Control & 6.54 & 7.82 & 7.89 & 7.94 & 7.55 & 6.81 & 7.86 & 7.92 & 7.99 & 7.65 \\
\hline Green tea extr. 5 g/l & 7.03 & 7.93 & 8.03 & 8.15 & 7.79 & 7.12 & 8.07 & 8.15 & 8.27 & 7.90 \\
\hline Moringa extr. 300 mg/l & 7.18 & 7.97 & 8.14 & 8.33 & 7.91 & 7.25 & 8.14 & 8.28 & 8.45 & 8.03 \\
\hline Garlic extr. 300 mg/l & 7.24 & 8.13 & 8.41 & 8.49 & 8.07 & 7.31 & 8.31 & 8.55 & 8.63 & 8.20 \\
\hline Licorice extr. 5 g/l & 7.95 & 8.20 & 8.73 & 8.81 & 8.42 & 8.02 & 8.39 & 8.88 & 9.01 & 8.58 \\
\hline Active yeast $5 \mathrm{~g} / \mathrm{l}$ & 8.23 & 8.72 & 9.13 & 9.29 & 8.84 & 8.28 & 8.90 & 9.22 & 9.44 & 8.96 \\
\hline Seaweeds extr. $3 \mathrm{~cm}^{3} / \mathbf{l}$ & 7.98 & 8.21 & 8.94 & 9.04 & 8.54 & 8.04 & 8.47 & 9.05 & 9.16 & 8.68 \\
\hline Mean (A) & 7.45 & 8.14 & 8.47 & 8.58 & & 7.55 & 8.31 & 8.58 & 8.71 & \\
\hline L.S.D. at $5 \%$ & A: 0 . & & B: 0.20 & & .40 & A: 0.6 & & B: 0.22 & & .44 \\
\hline
\end{tabular}


and Ibrahim (2015) on gladiolus; Emam (2010) and Karim et al. (2017) on tuberose and Al-Sahaf et al. (2017) on Mathiola incana.

These results might be attributed to the direct and/or indirect role of substances (nutrients, amino acids, vitamins, auxin, cytokinin and gibberellins) (Nagodawithana, 1991 and Sperenat, 1997), all those have better effects on the plant growth, consequently improving enzymatic system that reflected on the flowering of gladiolus.

The interaction between compost and natural stimulants was significant in the two seasons for the three studied flowering characters. The best overall results were obtained due to the use of compost at the high level (7.5 ton/fed) in combination with active dry yeast at $5 \mathrm{~g} / \mathrm{l}$ or seaweeds extract at $3 \mathrm{~cm}^{3} / 1$

\section{REFERENCES}

Abd El-Azim, W.M.; Badawy, M.Y.M. and Khater, R.M.R. (2016). Effect of Mycorrhiza and phosphate dissolving bacteria and licorice extract on growth and oil productivity of Foeniculum vulgare, mill. Plant under Baluza in North Sinai conditions. Middle East J. of Applied Sciences, 6(4):990-1002.

Abdel-Mola, M.A.M. (2017). Response of Gladiolus grandiflorus Plants to Compost Fertilization and Some Natural Stimulants. Ph.D. Thesis, Fac. Agric., Minia University.

Abdou, M.A.H.; Aly, M.K. and Ahmed, A.S.A. (2013). Effect of compost, biofertilization and some vitamins addition on Gladiolus grandiflorus J. Plant Production, Mansoura Univ., 4(12):1751-1761.

Abdou, M.A.H. and Ibrahim, T.I.E. (2015). Response of Gladiolus cv. Carmen to compost, biofertilization and some vitamin treatments. The $1^{\text {st }}$ Conf. of SSFOP "Future of Ornamental Plants in Egypt", Cairo, Egypt, 22/2/2015, Scientific J. Flowers \& Ornamental Plants.
Ahmed, A.S.A. (2013). Physiological Studies on Gladiolus Plant. M.Sc. Thesis, Fac. Agric. Minia Univ. Egypt., 1-159.

Ahmed, I.; Saquib, R.U.; Qasim, M.; Saleem, M.; Khan, A.S. and Yaseen, M. (2013). Humic acid and cultivar effects on growth, yield, vase life and corm characteristics of gladiolus. Chilean J. of Agri. Res., 73(4):339-344.

Alma'thedee, A.F. and Bairam, B.S. (2014). Study efficiency of plant and seaweed extracts on growth and flowering of gladiolus under plastic house. J. of Tikrit University for Agri. Sci., Special Issue, 91-96.

Al-Rashedy, G.A.H. (2010). Effect of Some Treatments on Growth, Flowering, Corms and Cormels Yield of Two Gladiolus Hortulanus Cultivars. M.Sc. Thesis, Fac. of Agric., Univ. of Mosul. Iraq.

Al-Sahaf, F.H.R.; Al-Zurfi M.T.H.; Saheb, A.R. and Saheb, T.H. (2017). Effect of spraying yeast extract and salicylic acid on growth and flowering of Mathoila incana L. Kufa J. for Agri. Sci., 9(1):3252.

Armoskaite, V.; Ramanauskiene, K.; Maruska, A.; Razukas, A.; Dagilyte, A.; Baranauskas, A. and Briedis, V. (2011). The analysis of quality and antioxidant activity of green tea extracts. J. of Medicinal Plants Res. 5(5):811-816.

Atta-Alla, H.K.; Zaghloul, M.A. and Hashish, K.H. (2003). Effect of organic manure and NPK fertilizers on vegetative growth, flowering and chemical composition of some gladiolus cultivars. Annals of Agric. Sci., Moshtohor, 41(2):680-691.

Chandar, I.; Rawat, I.; Lakhawat, S.S. and Yadav, K.K. (2012). Effect of organic manures and biofertilizers on the yield parameters of Gladiolus cv. White prosperity. Ecol., Environ. and Conservation Paper,18(1):91-94. 
Conte, C.A.M.; Ruppenthal, V.; Zigiotto, D.C.; Bianchini, M.I.F. and Baches, C. (2001). Organic fertilization for the culture of the gladiolus. Scientia Agraria Paranaensis, 1(1):33-41 (C.F. CAB Anst., ENAL).

Crouch, I.J and Van Staden, J. (1992). Effects of seaweed concentrate on the establishment and yield of greenhouse tomato plants. J. Appl. Phycol., 4:291296.

Dongardive, S.B.; Golliwar, V.J. and Bhongle, S.A. (2007). Effect of organic manure and biofertilizers on growth and flowering of Gladiolus cv. White Prosperity. Plant Archives, 7(2):657658.

El-Desouky, S.A.; Waneis, A.L.A. and Khedr, Z.M.A. (1998). Utilization of some natural plant extracts (garlic and yeast) as seed-soaked materials to squash (Cucurbita pepo, L.). Effect on growth, sex expression and fruit yield and quality. Ann. Agric., Sci., Moshtohor, 36(2):839-854.

Emam, O.N.K. (2010). Effect of Treating Tuberose Plants (Polianthes tuberosa, L.) With Some Organic Extracts to Improve Growth and Flowering. Ph.D. Thesis, Fac. Agric., Ain Shams Univ., 1-105.

Gangadharan, G.D. and Gopinath, G. (2000). Effect of organic and inorganic fertilizers on growth, flowering and quality of Gladiolus cv. White Prosperity. Karnataka J. Agric. Sci., 13(2):401-405.

Hassan, A.A. (2016). Response of Gladiolus Plant to Some Fertilization and Antioxidant Treatments. Ph.D. Thesis, Fac. Agric., Minia University.

Karim, K.B.; Kumar, N.V.; Raghupati, B. and Pal, A.K. (2017). Effect of biostimulants on growth and floral attributes of tuberose (Polianthes tuberosa, L.) cv. Prajwal. Int. J. Curr. Microbiol. App. Sci., 6(6):2557- 2564.
Khalil, A.R.M. (2015). Physiological Studies on Gladiolus Plant. M.Sc. Thesis, Fac. Agric. Minia Univ. Egypt, 1-146.

Khan, S.; Khan, A.; Iqbal, A. and Rehman, M. (2002). Effect of different media on growth and quality of gladiolus (Gladiolus hortulanus cv. Jacksonville Gold). Asian J. of plant Sci., 1(6):670671.

Khanam, R.; Kundu, D. and Patra, S. (2017). Integrated nutrient management on growth, quality, and yield and soil fertility of gladiolus in lower Gangetic plain of India. International J. of Current Microbiology and Appl. Sci., 6(4):453459.

Khattab, M.; Raslan, M.; Nabih, A. and Selim, A. (2016). Effect of some fertilizer treatments on the growth of cormels of Gladiolus and corms production. Alexandria Science Exchange Journal, 37(4):561- 571.

Leonardo, M. and Barbara, D.L. (2011). Organic and mineral soil fertilization in gladiolus. Compost Sc. and utilization, 19(3):178-179.

Maynard, A.A. (1991). Intensive vegetative production using composted animal manures. The Connecticut Agricultural Experiment Station. New Haven, Bulletin, 894.

Moore, T.C. (1979). Biochemistry and Physiology of Plant Hormones. Sprenger-Verlag, New York, USA.

MSTAT-C (1986). A microcomputer program for the Design Management and Analysis of Agronomic Research Experiments (Version 4.0), Michigan State Univ., U.S.A.

Nagodawithana, W.T. (1991). Yeast Technology. Universal Foods Corporation Milwaukee, Wisconsin Published by Van Nostrand Reinhold, New York, 273 pp.

Pandey, A.; Singh, A. and Sisodia, A. (2013). Effect of vermicompost and bio- 
control agents on growth and flowering of Gladiolus cv. J.V. GOLD. The Asian J. of Hort., 8(1):46-49.

Pereira, M.T.; Silva, T.J.; Bonfim-Silva, E.M. and Mazzini-Guedes, R.B. (2016). Applying wood ash and soil moisture on gladiolus (Gladiolus grandiflorus) cultivation. Australian J. of crop Sci., 10(3):393-401.

Phiri, C. and Mbewe, D.N. (2010). Influence of Moringa oliefera, leaf extracts on germination and seedling survival of three common legumes. Int. J. Agric. Biol., 12:315-317.

Pradeep, K.; Manivannan, K. and Kumar, S.R. (2014). Effect of organic nutrients on growth, flowering and yield of
Gladiolus grandiflorus, L. The Asian J. of Hort., 9(2):416-420.

Sankari, A.; Anand, M. and Arulmozhiyan, R. (2015). Effect of biostimulants on yield and post-harvest quality of Gladiolus cv. White prosperity. The Asian J. of Hort., 10(1):86- 94.

Skoog, F. and Miller, C. (1957). Biological action of growth substances. Cambridge Univ. Press Camb., 1957-2000.

Sperenat, M. (1997). Nitrogen Fixing Organisms, P.S. Chapman and Hall. London.

Subba Rao, N.S. (1984). Biofertilizers in Agriculture. Oxford, Com., New Delhi.

$$
\begin{aligned}
& \text { تأثير معاملات الكمبوست وبعض المنشطات الطبيعية على: } 1 \text { ـ النمو الخضري والصفات الزهرية لتبات }
\end{aligned}
$$

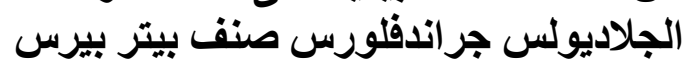

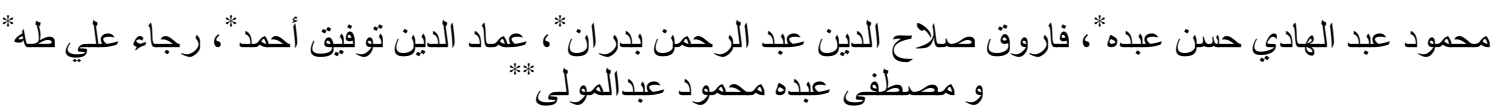

$$
\begin{aligned}
& \text { * قسم البساتين، كلية الزر اعة، جامعة المنيا، مصر. }
\end{aligned}
$$

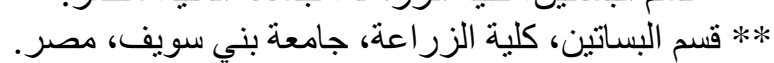

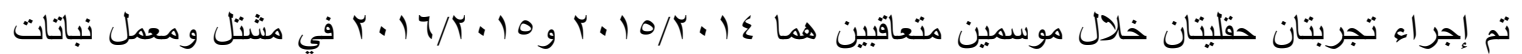

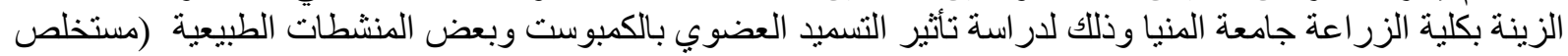

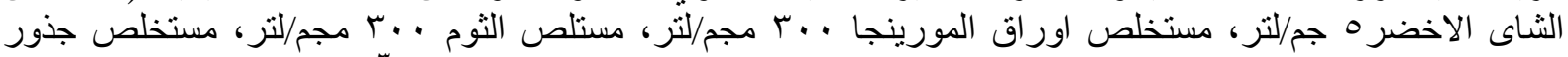

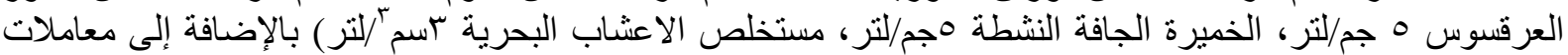

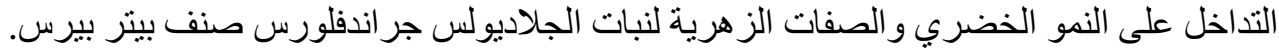

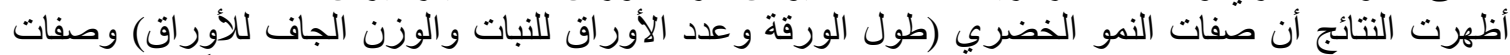

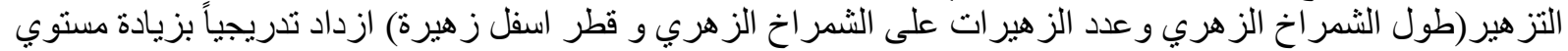

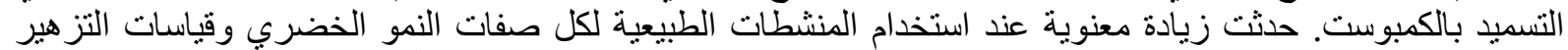

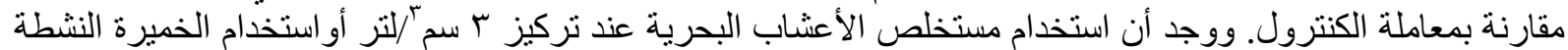

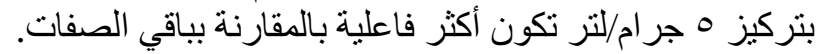

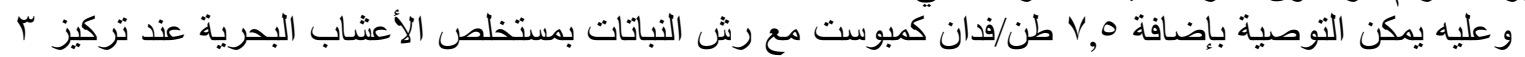

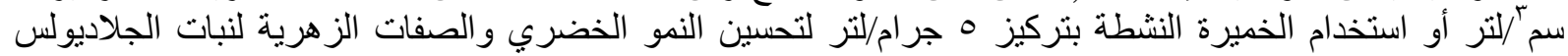
جر اندفلورس صنف بيتر بيرس. 